\title{
Shareholder Wealth Maximization and Social Welfare: A Utilitarian Critique
}

\author{
Thomas M. Jones ${ }^{1}$ \\ University of Washington \\ Will Felps \\ University of New South Wales
}

\begin{abstract}
Many scholars and managers endorse the idea that the primary purpose of the firm is to make money for its owners. This shareholder wealth maximization objective is justified on the grounds that it maximizes social welfare. In this article, the first of a two-part set, we argue that, although this shareholder primacy model may have been appropriate in an earlier era, it no longer is, given our current state of economic and social affairs. To make our case, we employ a utilitarian moral standard and examine the apparent logical sequence behind the link between shareholder wealth maximization and social welfare. Upon close empirical and conceptual scrutiny, we find that utilitarian criteria do not support the shareholder model; that is, shareholder wealth maximization is only weakly linked to social welfare maximization. In view of the dubious validity of this sequential argument, we outline some of the features of a superior corporate objective-a variant of normative stakeholder theory. In the second article, we will advance and defend our preferred alternative and then discuss some institutional arrangements under which it could be implemented.
\end{abstract}

KEY WORDS: shareholder wealth maximization (SWM), corporate objective function, normative corporate governance, utilitarianism, social welfare

"If you will pardon me for being personal, it makes a great difference in my attitude toward my job as an executive officer of the General Electric Company whether I am

a trustee of the institution or an attorney for the investor. If I am a trustee, who are the beneficiaries of the trust? To whom do I owe my obligations?"-Owen D. Young, former Chairman of GE (Dodd, 1932: 1154)

$\mathrm{T}$ HE ISSUE ARTICULATED BY MR. YOUNG decades ago is still relevant today and is one that a considerable number of scholars have devoted themselves to, not in terms of particular companies, but for corporations in general. This article addresses the underlying question, one that lies at the very core of corporate governance for both practicing managers and business scholars: what should be the objective of corporations in a market capitalist economy? Put somewhat differently, what should managers, who govern these firms, strive to achieve? 
We aim to answer these questions in two separate articles. This first article will demonstrate the weaknesses of the conventional corporate objective-shareholder wealth maximization (SWM) - from a utilitarian perspective. It will focus on the apparent logic behind SWM as part of a set of institutions intended to produce maximal social welfare, the ultimate goal of utilitarian moral thought. After finding each of the four interconnected arguments that make up that logic quite weak, we suggest a path toward a credible alternative corporate objective. The second article will present and defend what we regard as a superior objective-a refined version of normative stakeholder theory — and outline the institutional mechanisms that would allow it to be implemented in the twenty-first-century US economy.

In both articles, we regard the corporate objective as an important part of a set of institutions that collectively comprise the economic system of the US-an advanced form of market capitalism. This perspective is fully compatible with Scott's definition of institutions: highly resilient social structures "composed of cultural-cognitive, normative, and regulative elements that ... provide stability and meaning to social life" (Scott, 1995: 33). This perspective also allows us to acknowledge the enormous difficulties involved in addressing the entire set of interconnected institutions that comprise the system and, in the process, to justify our focus on the important normative element of that system-the corporate objective.

In the process of examining the utilitarian weaknesses of SWM, we break new ground in the literatures of management and economics in two ways. First, we offer a critique of SWM that is unique in the long history of scholarly criticism of the primacy of shareholder interests; no extant scholarship has systematically analyzed the utilitarian foundations of SWM. Second, within this analysis, we demonstrate how the interplay of positive evidence and normative concepts can be used to shed light on important normative questions, an approach called positive-normative triangulation and endorsed by advocates of both normative stakeholder theory (Donaldson, 2006, 2007, 2012) and SWM (Maitland, 1994).

The article is structured as follows. We first present a case for re-examining SWM as an institutionalized component of the US brand of market capitalism and justify our decision to scrutinize the corporate objective rather than to propose reforms to the institutions that surround that objective. We then discuss various aspects of utilitarianism, which is widely regarded to be the moral foundation of both market capitalism and SWM as a corporate objective function. Next we undertake an extensive four-stage analysis of the apparent logic behind the social welfare claims related to SWM. After finding all four of these sequential arguments to be conceptually and/ or empirically weak, we conclude that the overall logical argument leading from SWM to maximal social welfare is dubious indeed. We then offer the broad outlines of a superior corporate objective - a variant of normative stakeholder theory - that we will formally present and defend in the second article.

\section{THE CONVENTIONAL CORPORATE OBJECTIVE}

The dominant normative mandate for managers of US corporations is the maximization of the wealth of company shareholders, primarily through the maximization of 
profits. Indeed, a number of studies reveal that directors of US corporations identify their mission as increasing shareholder wealth (Alexander, 1999; Korn/Ferry International, 2000) and that this prioritization has intensified over time (Gordon, 2007; Pye, 2002). As articulated early on by Adolph A. Berle:

[A]ll powers granted to a corporation or to the management of a corporation, or to any group within the corporation ... [are] at all times exercisable only for the ratable benefit of all the shareholders as their interest appears. (Berle, 1931: 1049)

Although this conventional view has been championed by many-Nobel Prizewinning economists (e.g., Friedman, 1962, 1970), prominent scholars in financial economics (e.g., Jensen, 2002), management scholars (e.g., Sundaram \& Inkpen, 2004), members of the business press (Rappaport, 1986), and many of the most respected corporate executives of our time - the general idea antedates managerial capitalism by over two centuries in the form of Adam Smith's Wealth of Nations (1776). ${ }^{2}$

Although there are a number of other terms for the pursuit of shareholder financial interests as the normative mandate for corporate governance-e.g., profit maximization, stock value maximization, shareholder primacy, and the shareholder model - their meanings are similar. Jensen (2002) provides a slight variation on this theme-firm value maximization, which includes returns to debt holders as well as shareholders. For the sake of consistency, we will use the term shareholder wealth maximization, abbreviated to SWM, throughout this article. ${ }^{3}$

Over the years, the notion that managers have obligations to corporate constituents in addition to shareholders has gained intellectual traction among (a) advocates of corporate social responsibility, beginning with Bowen (1953), and (b) proponents of normative versions of stakeholder theory, articulated well by Donaldson and Preston (1995). Nonetheless, the perspectives of supporters of the conventional view and the demands of investors, often characterized as "Wall Street," remain dominant. What has been called the shareholder model is often seen as a core element of US style market capitalism (Lindblom, 2002). Note, however, that there are other variants of capitalism, such as those practiced in much of the European Union, that do not regard shareholder wealth maximization as the sole objective function for managers (Fannon, 2003; Rebérioux, 2002). Our critique of SWM is, by extension, a critique of those forms of capitalism that do enshrine SWM as essential to the functioning of the economic system. Importantly however, our analysis does not apply to capitalism writ large (cf. Keay, 2012; Meyer \& Höllerer, 2010).

\section{WHY RECONSIDER THE SWM OBJECTIVE?}

Undertaking a thorough critique of SWM based on its social welfare virtues would hardly seem worthwhile if the corporate objective and the institutions that surround it were consistently leading to good outcomes. However, the overall upward trend in aggregate wealth cannot mask some significant macro-level economic problems - some enduring, others episodic. Although the causes of economic and social problems are certainly complex and multifaceted, incentives related to shareholder wealth maximization probably played, and continue to play, a significant role in some 
of them. For example, the emergence of the subprime mortgage market "bubble" was related in part to: (1) the desire of lenders to make profitable mortgage loans; (2) the desire of financial institutions to fulfill the demand for collateralized home mortgages; and (3) the apparent willingness of rating firms (e.g., Standard and Poor's) to give high ratings to these debt instruments in response to the wishes of their issuers, who pay for the rating services. In this case, there were profit-based incentives to approve, bundle, and endorse mortgages regardless of the creditworthiness of the home owners involved.

In addition, the profit motive lies behind several cost-cutting initiatives undertaken by firms that have had the effect of benefiting shareholders at the expense of other stakeholders, employees in particular. For example, the quest for lower labor costs has led to the offshoring of numerous jobs, resulting in unemployment/underemployment and stagnant or deteriorating incomes for many lower and middle class workers, setbacks that may not be temporary (Krugman, 2007). Furthermore, cost reduction pressures have been largely responsible for a declining incidence of corporate pension plans as well as reductions in health care coverage for employees in the corporate sector. Indeed, some companies have undertaken "strategic bankruptcies" in order to renege on pensions promised to workers (Orr, 1998). In the analyses of a number of commentators, the combination of these and others developments has resulted in a substantial shrinking of the middle class as well as marked increases in inequality in the distributions of wealth and income in the US (Krugman, 2007). With these observations in mind, we suggest that the set of institutions that include the pursuit of SWM should be carefully scrutinized with the intent of promoting greater social welfare in the US.

In general terms, there are two approaches to economic reform as fundamental as the one that concerns us here. One could accept the dominant corporate objective-SWM-as it is and attempt to restructure the institutional arrangements that surround it in order to allow market forces to improve the system. Several decades of analysis and theoretical work by economists have produced numerous proposals for reform, some of which have been tried. For example, the Sherman Antitrust Act and the legislation creating the Federal Trade Commission have attempted to limit extreme deviations from competitive markets. Similarly, the Securities and Exchange Commission has promulgated numerous disclosure rules based on the assumption that better information will help promote more efficient financial markets. In addition, regulatory agencies such as the Environmental Protection Agency and the Consumer Products Safety Commission have been established to correct flaws in the operation of markets. While many of these reforms have had positive outcomes, some major economic problems persist while others continue to emerge.

In addition, the scale of changes needed to modify existing institutions in order to create the requisite market conditions would be monumental. In a classic article entitled "The Theory of the Second Best" (described more fully below), Lipsey and Lancaster (1956) theoretically demonstrate that all of the assumptions of perfect competition must hold in order for SWM to produce maximal social welfare; bringing markets closer to the conditions of perfect competition does not necessarily increase, and may decrease, social welfare. Coupled with the highly influential involvement 
of large corporations in the political process, often with the intent of defeating or deflecting regulatory reforms (Hillman, Keim, \& Schuler, 2004), the future of major reforms to economic institutions is not bright. As for corporations actually advocating major reforms, consider the following rhetorical question: why would a firm, steeped in the logic of corporate self-interest (SWM), suddenly advocate reforms intended to benefit others? Put differently, why would corporations that are expected to act in their own interests in economic affairs act in "the public interest" the political arena? Indeed, most savvy corporations regard political involvement as "economic advancement by other means."

In summary, although SWM might be a perfectly acceptable corporate objective under some conditions, those conditions do not exist. Furthermore, the historical project of attempting to "perfect" the institutions intended to establish sufficiently competitive market conditions is one of long duration and uncertain results and one to which we have nothing to add. Therefore, we focus our attention on revising the normative objective that guides corporate governance.

Our resolve to undertake this critique is bolstered by a strongly held belief that ideas, particularly those that underpin key economic institutions, can make a difference in the way that society functions. We fully endorse Keynes's classic quotation:

The ideas of economists and political philosophers, both when they are right and when they are wrong, are more powerful than is commonly understood. Indeed the world is ruled by little else. Practical men, who believe themselves to be quite exempt from any intellectual influence, are usually the slaves of some defunct economist. ... I am sure that the power of vested interests is vastly exaggerated compared with the gradual encroachment of ideas. (Keynes, 1936: 383)

Historically, the writings of Marx (1867) are a prime example of this phenomenon, as are the writings of Keynes himself. In the contemporary economy, the changes wrought in response to the application of agency theory to corporate governance (Jensen \& Meckling, 1976) also serve to underscore this point.

In addition, we are responding to an important article by Sumantra Ghoshal, published after his death, in which he urged management scholars to begin the process of replacing "bad management theories," which he argued were "destroying good management practices" (Ghoshal, 2005; see also Ghoshal, Bartlett, \& Moran, 1999; Ghoshal \& Moran, 1996). His point was that many management theoriese.g., agency theory and transactions cost economics - are based on the assumption that human beings are largely self-interested, even opportunistic (self-interested and guileful) - and that such theories condition people to expect such behavior from others and legitimate that behavior in themselves. The cognitive frameworks formed through this process can become self-fulfilling prophesies, thus causing the underlying theories to become more descriptively valid. ${ }^{4}$ He goes on to lament that management theory has neglected a commitment to either informing management practice or furthering the welfare of the societies that are affected by management practice. Others have also sounded this alarm in various ways (Ferraro, Pfeffer, \& Sutton, 2005; Frank \& Schulze, 2000; Frank, Gilovich, \& Regan, 1993; Kuttner, 1999; Ratner \& Miller, 2001; Walsh, Weber, \& Margolis, 2003). In particular, Fer- 
raro, Pffeffer, and Sutton (2005) outline how current management theories affect the realities they describe through their influence on institutional designs, social norms, and assumptions embedded in language. Collectively, this body of work on self-fulfilling prophesies highlights both: (1) the practical difficulty of distinguishing between descriptive theory (i.e., "what is") and normative theory (i.e., "what ought to be"); and (2) the fact that is-theory and ought-theory are mutually influential, both in academia and beyond.

In the business ethics community, Donaldson has forcefully made a similar point. In a number of venues (Agle, Donaldson, Freeman, Jensen, Mitchell, \& Wood, 2008; Donaldson, 2006, 2007, 2008, 2012), Donaldson critiques the business ethics literature for engaging in sophisticated discourses about how businesses ought to function, while often neglecting how business actually functions in the real world. Conversely, he criticizes much of the rest of the management literature for developing rigorous descriptions of the world, while remaining more or less silent about the normative implications thereof. He suggests that, going forward, our theories should attempt to jointly consider the normative implications of descriptive findings, and conversely, consider the kinds of data that could answer important normative questions. He dubs this approach to research "positive-normative triangulation." Similarly, Freeman and colleagues (Freeman, Harrison, Wicks, Parmar, \& De Colle, 2010) are concerned with the "separation thesis"- the notion that business and ethics can be seen as independent. Rejecting the "non-overlapping magisteria argument" (e.g., Gould, 1999), they suggest that future research should consider how the practice of business creates and is justified by moral standards. Some advocates of SWM also endorse positive-normative triangulation (e.g., Maitland, 1994). We begin to fulfill these ambitions with an empirically grounded critique of the moral foundation of the reigning normative corporate objective-SWM.

\section{THE MORAL FOUNDATIONS OF THE INSTITUTIONS OF MARKET CAPITALISM}

Promoting social welfare is widely regarded to be the primary function of social systems, prominently including the economic system (Kaplow \& Shavell, 2001). Indeed, the classic justification for the economic system we call market capitalism is fundamentally utilitarian, a moral perspective that aims to achieve the greatest social benefit net of social cost or, more colloquially, "the greatest good for the greatest number" (Audi, 2007; Mill, 1863; Sidgwick, 1879). Utilitarianism is thought to take two forms - act and rule. Act utilitarianism instructs the agent to make the decision that results in the greatest net social benefit with respect to the decision at hand. Rule utilitarianism, on the other hand, directs the agent to follow rules that are intended to produce the greatest net social benefit over time. Importantly, for rules to be morally binding: (1) most agents must follow the rules; and (2) the system of rules must actually produce the desired results. To illustrate the difference, suppose that a criminal defense attorney knows that his/her client is guilty of murder. Providing a zealous defense intended to gain an acquittal can be justified as an application of rule utilitarianism; the attorney follows a rule that is part of a criminal justice system 
intended to produce optimal outcomes over time. Providing a weak defense or no defense at all could be justified as an application of act utilitarianism; the attorney seeks justice in the case at hand and wants to avoid a repeat offense. As explained below, the difference between these two forms of utilitarianism is important to the development of our alternative stakeholder theory.

A social welfare emphasis as well as a rule utilitarian logic are readily apparent in the original insights of Adam Smith as well as those of contemporary scholars:

By pursuing his own interest he frequently promotes that of the society more effectually than when he really intends to promote it. (Smith, 1776: 488-89)

Two hundred years of work in economics and finance implies that in the absence of externalities and monopoly (and when all goods are priced), social welfare is maximized when each firm in an economy maximizes its total market value. (Jensen, 2002: 239)

[G]etting these standards right is important if we are to maximize long-term benefits flowing to society. (Wallman, 1998: 810)

$[\mathrm{H}]$ ow do we govern firms so as to increase social welfare (as proxied by maximization of shareholder value across the general market)? (Gordon, 2007: 1469)

As these statements indicate, SWM is a rule-utilitarian element of a capitalist system that is intended to provide long-term benefits to society. ${ }^{5}$

\section{THE OBJECTIVE OF THE FIRM: COMPETING NORMATIVE THEORIES}

This article rejoins a controversy that some have called the shareholder/stakeholder debate (e.g., Freeman, Wicks, \& Parmar, 2004; Sundaram \& Inkpen, 2004), which focuses on the two normative corporate governance questions articulated above: (1) in whose interests should the corporation be run? and (2) what should managers, who govern these corporations, strive to achieve? These questions have inspired scholarly attention from several disciplines-economics (Friedman, 1970; Jensen, 2002), law and political science (Bainbridge, 1993, 2002; Blair \& Stout, 1999; Ehrlich, 2005; Green, 1993; Lee, 2005; Rebérioux, 2007; Sheehy, 2005; Smith, 1998; Stout, 2012, 2002), and management (Bowen, 1953; Davis, 1973; Freeman et al., 2010; Ghoshal et al., 1999; Jones, 1980; Laplume, Sonpar, \& Litz, 2008; Leavitt, 1958; Marcoux, 2000; Post, Preston, \& Sachs, 2002; Quinn \& Jones, 1995; Sundaram \& Inkpen, 2004) - thus providing ample testimony to their moral and pragmatic importance. A more extensive quotation from Wallman expresses the vital nature of the controversy quite well:

This debate as to whether directors owe their obligations primarily to the shareholders . . could be viewed as not much more than, perhaps, an interesting discussion if the answers did not have such real world consequences. We care about this issue not as an intellectual exercise but because getting these standards right is important if we are to maximize long-term benefits flowing to society. (Wallman, 1998: 810)

In what follows, we focus on the facet of the debate where novel contributions can be made. Specifically, we offer a critique of SWM that is unique in the long history 
of scholarly criticism of the primacy of shareholder interests; no extant scholarship has systematically critiqued the utilitarian foundations of shareholder wealth maximization. Second, within this critique, we demonstrate how the interplay of positive evidence and normative concepts can be used to shed light on important normative questions.

Advocates of SWM as a corporate objective and supporters of normative stakeholder theory, SWM's most fully articulated alternative, have sparred over issues related to: (1) private property, (2) the protection of individual freedoms, (3) the rights of shareholders versus those of other stakeholders, (4) the contractual obligations of managers, (5) agency relationships, and (6) public policy considerations, among others (Bainbridge, 1993, 2002; Boatright, 1994, 2006; Freeman et al., 2004; Friedman, 1962, 1970; Henderson, 2001; Jensen, 2002; Stout, 2002, 2012; Sundaram \& Inkpen, 2004). These arguments have been presented elsewhere by these and other well-informed scholars and nothing we could add would resolve the underlying issues. However, we see nothing in the arguments in favor of SWM that would render our utilitarian analysis moot. Therefore, after outlining the basic tenets of normative stakeholder theory, we concentrate our attention on our uniquely utilitarian analysis, an examination of the logical link between SWM and maximal social welfare.

Note that, while we have posited that there are two clear and opposing answers to the normative question regarding the appropriate objective of the firm, we regard this perspective as a simplifying assumption. There are differences of opinion within each group and there are some works that are difficult to place into either SWM or normative stakeholder theory camps (e.g., Erhard, Jensen, \& Zaffron, 2008; Velamuri \& Venkataraman, 2005). However, to use an analogy from statistics, since there seems to be much more variation (in assumptions and conclusions) between groups than within groups, it makes sense to move to a group level of analysis. Furthermore, although Freeman, often described as the progenitor of stakeholder theory, has called for an end to the Friedman/shareholder vs. Freeman/stakeholder debate, we continue to believe that important issues remain regarding both ends-shareholder wealth vs. stakeholder interests - and means - the best way of achieving either of these goals. In particular, although both sets of firm objectives aim to improve collective welfare and organizational effectiveness, they are based on radically different empirical understandings of the economic and social world. Thus, the debate is about webs of empirical relationships in addition to underlying moral ambitions. As noted above, this article focuses on a utilitarian critique of SWM, leaving the presentation and defence of our preferred alternative, a refined version of normative stakeholder theory, to the second article. Therefore, in the discussion that follows, we present only the broad outlines of normative stakeholder theory to serve as an alternative to SWM.

\section{Normative Stakeholder Theory}

Stakeholders can be defined as "individuals and constituents that contribute, either voluntarily and involuntarily, to (the corporation's) wealth-creating capacity" (Post et al., 2002: 19). Normative stakeholder theory holds that managers have a moral 
responsibility to regard the interests of certain corporate constituent groups, including shareholders, as legitimate. ${ }^{6}$ In recent years, stakeholder theorists have drawn on a variety of moral philosophical traditions to specify the ways that stakeholder interests can be taken into account. Contributions in this vein involve: (a) feminist ethics/ethics of care (Machold, Ahmed, \& Farquhar, 2008; Wicks, Gilbert, \& Freeman, 1994); (b) Kantian ethics (Bowie, 1998; Evan \& Freeman, 1993); (c) norms of sociality (Hendry, 2001, 2004); (d) virtuous treatment (Moore, 2012; Payne, Brigham, Broberg, Moss, \& Short, 2011; Solomon, 1992), (e) stakeholder rights derived from social contracts (Donaldson \& Dunfee, 1994; van Oosterhout, Heugens, \& Kaptein, 2006; Soule, Hedahl, \& Dienhart, 2009); and (f) principles of fairness (Bosse, Phillips, \& Harrison, 2009; Hosmer \& Kiewitz, 2005; Phillips, 1997, 2003); (g) religion and spirituality (Beekun \& Badawi, 2005; Schwartz, 2006). While these scholars may disagree on the details, the normative core of stakeholder theoryi.e., regarding stakeholder interests as legitimate-is widely accepted (Donaldson \& Preston, 1995; Jones, Felps, \& Bigley, 2007).

\section{A Rule Utilitarian Mandate for SWM}

Although the enhancement of social welfare is at the normative heart of many justifications for SWM and many versions of normative stakeholder theory, this common objective is rarely acknowledged by the opposing camps. This confusion is probably due, at least in part, to the less-than-obvious logic underlying SWM as a normative objective. It is not abundantly clear how self-interested behavior on the part of individuals and firms leads to good (moral) outcomes for society, a view captured in a more complete rendition of Adam Smith's oft-quoted lines from The Wealth of Nations:

"It is not from the benevolence of the butcher, the brewer, or the baker that we expect our dinner, but from their regard to their own self-interest."

A person "is led by an invisible hand to promote an end which was no part of his intention."

"By pursuing his own interest he frequently promotes that of the society more effectually than when he really intends to promote it." (Smith, 1776: 488-89).

Through the workings of the market, the pursuit of self-interest is a necessary condition for the enhancement of aggregate social welfare, an archetypical application of rule utilitarian moral philosophy. Jensen provides a more elaborate explanation of the link between self interest and social welfare in the context of modern corporations.

Two hundred years of work in economics and finance implies that in the absence of externalities and monopoly (and when all goods are priced), social welfare is maximized when each firm in an economy maximizes its total market value.... [A] firm taking inputs out of the economy and putting its output of goods and services back into the economy increases aggregate welfare if the prices at which it sells the goods more than cover the costs it incurs in purchasing the inputs. Clearly the firm should expand its output as long as an additional dollar of resources taken out of the economy is valued by the consumers of the incremental product at more than a dollar. Note that the difference between these revenues and costs is profits. This is the reason (under the assumption that there are no 
externalities or monopolies) that profit maximization leads to an efficient social outcome. (Jensen, 2002: 239-40)

Our interpretation of the argument behind Jensen's quote is that improvements in social welfare will be best achieved in accordance with the following theoretical logic: In the context of competitive markets, shareholder wealth maximization leads to economic efficiency. Efficient markets, because they make the most productive use of society's resources, lead to greater levels of aggregate economic wealth. Greater economic wealth leads to greater social welfare. This logical chain justifies the functioning of the market capitalist system and the behavior of the firms that populate it. Note that this logic is one of rule utilitarianism and that it depends on certain conditions.

To elaborate, no defender of shareholder wealth maximization would claim that profit maximization on the part of individual firms, absent the context of reasonably competitive markets, maximizes social welfare. Profit maximizing behavior on the part of unregulated monopolies, to choose an obvious example, clearly does not enhance efficiency, aggregate economic welfare, or social welfare. Nor would anyone claim that social welfare is maximized with respect to every individual shareholder wealth maximizing decision (Gordon, 2007). Indeed, most economists would agree that some decisions that increase firm wealth-e.g., disposing of toxic wastes from a tannery into a pit near Woburn, Massachusetts ${ }^{7}$ - clearly do not. SWM is part of a rule utilitarian system intended to maximize social welfare over time.

Two important points are raised by the sequence of causal connections listed above. First, the sequence suggests that there are four distinct empirical issues invoked by this formulation of how SWM leads to social welfare. Each of these four claims is amenable to empirical examination and can be supported or disconfirmed by evidence. Second, for SWM to be justified by this utilitarian logic, a number of interrelated conditions must hold. If any link of the causal chain is totally missing or if multiple links are weak, the validity of the entire argument is threatened. That is: (1) if markets are not sufficiently competitive; or (2) if focusing on shareholder wealth does not lead to efficient firms; or (3) if efficient firms do not lead to improved aggregate economic welfare; or (4) if economic wealth is not related to social welfare, then this rationale for shareholder wealth maximization cannot be justified by this utilitarian logic. In the following section, we argue that there are important weaknesses at each of the four steps in the logical sequence leading from SWM to maximal social welfare.

\section{The Logical Sequence from SWM to Social Welfare}

\section{Competitive Markets}

Economic models linking shareholder wealth maximization to economic efficiency are based on the assumption of perfectly competitive markets. Perfectly competitive markets, in turn, describe an ideal condition in which markets quickly move to economic equilibrium (Stigler, 1957). This ideal holds only when: (a) there are a large number of buyers and sellers in product markets, (b) both buyers and sellers have complete and costless information about prices, (c) all firms have equal 
access to technologies and resources, (d) any firm may enter or exit the market, (e) the actions of sellers are independent, and (f) the actions of buyers are independent (McNulty, 1968).

In addition, Jensen (2002), as quoted above, stipulates that the link between shareholder wealth maximization and social welfare maximization requires that monopolies and externalities do not exist and that all goods be priced, an important assumption since perfect competition is competition based on price. Although economists have long admitted that this set of conditions holds only in a small minority of markets (e.g., Comanor, 1967; Gale, 1972), the implications remain controversial (Arnott, Greenwald, Kanbur, \& Nalebuff, 2003; Stigler, 1957).

Furthermore, one generally accepted perspective, "the general theory of second best" (introduced above), holds that "the attainment of a Paretian optimum requires the simultaneous fulfillment of all the optimum conditions" and, importantly, that the fulfillment of more conditions in no way guarantees a "second best" solution (Lipsey \& Lancaster, 1956: 11). This theorem suggests that if markets are imperfect in any way - and many seem to be imperfect in multiple ways-optimal outcomes are not achievable, and outcomes even approaching optimal are elusive as well.

Other scholars have argued that some markets may be sufficiently contestable to allow reasonable competition to prevail (Baumol, Panzar, \& Willig, 1982). That is, as long as entry to, and exit from, markets is nearly costless, industries need not be characterized by large numbers of sellers. However, barriers to entry and exit are significant in many markets, and markets are often dominated by a few firms.

Although perfect competition exists in relatively few markets, competitive certainly describes many others. The Boeing/Airbus duopoly in the commercial airframe manufacturing industry is one case in point. More generally, competitive behavior often takes the form of entrepreneurship and innovation, rather than price (White, 1986). The contrast between Apple (innovative products priced well above the competition) and Wal-Mart ("always low prices" on undifferentiated products) is instructive here. Differentiation strategies are designed to create mini-monopolies for a firm's products or services, allowing it to avoid the rigors of perfect competition. Differentiation strategies also help assure that market equilibrium will never be achieved. In other words, the competitive conditions described here closely resemble those of the "Austrian" economic perspective (e.g., Jacobson, 1992). Markets tend toward equilibrium and do apply competitive pressures on firms to strive for efficiency, but market discipline is rarely either swift or sure. Rather, many markets provide a rough sorting of efficient and inefficient firms, rewarding the former and penalizing, but infrequently eliminating, the latter. Therefore, the structure and functioning of actual markets in the US (or anywhere else) do not match the conditions necessary for a utilitarian justification for SWM.

If one's aim is to build elegant theoretical models of ideal economic systems, violations of the assumptions of perfect competition are not necessarily problematic (Demsetz, 1975). However, if one is trying to create a normative model for how managers can best improve societal welfare within the constraints of market competition, such violations of foundational assumptions are important. For the purposes of this article, it is sufficient to conclude that, even though elements of competition 
certainly do exist, a normative argument that depends on the widespread existence of intensely competitive markets, wherein firms compete on price, is of questionable validity. In other words, if the conditions required for perfect competition actually existed in twenty-first-century US market capitalism, SWM might be a viable means of maximizing social welfare. These conditions do not exist, so it seems wise to seek credible alternative corporate objectives.

\section{SWM and Firm Efficiency}

Even if the assumption of widespread highly competitive markets could be sustained, would shareholder wealth maximization necessarily lead to economic efficiency? A preliminary look at some empirical evidence leads to some potentially disconfirming conclusions. Indeed, meta-analyses of the large body of research on corporate social performance (CSP) and financial performance (FP) find a positive link (Margolis \& Walsh, 2003; Orlitzky, Schmidt, \& Rynes, 2003; Orlitzky, 2011), ${ }^{8}$ increasing our confidence that at least some of the discretionary, socially minded activities engaged in by firms have positive long-term impacts on financial performance.

Furthermore, Ghemawat and Costa (1993) provide a conceptual distinction that helps explain why a direct quest for shareholder returns may actually undermine that objective (see also Ghoshal, 2005; Stout, 2012). They explain how the pursuit of static efficiency - the immediate consequences of decisions, such as quarterly profits - often undermines dynamic efficiency — a firm's ongoing ability to create value for shareholders (see also Ghoshal \& Moran, 1996). ${ }^{9}$ Unfortunately, research in behavioral finance has found that investments in static efficiency are more transparent, better understood, and more highly valued by the market than investments in dynamic efficiency (Shiller, 2000). Since the market seems to systematically undervalue investments in dynamic efficiency, shareholder value can be harmed by the pursuit of short-term share price increases. As such, a number of scholars argue that pure profit-seeking can actually undermine profits in the long-run (Dore, 1983; Ghoshal et al., 1999; Hosmer, 1994). Indeed, a recent empirical study by de Luque, Washburn, Waldman, and House (2008) suggests that firms led by CEOs who adopt stakeholder values as an operating philosophy outperform firms led by CEOs who hold economic values to be most important. This study supports Ghoshal and Moran's (1996) claim that economic values undermine the visionary leadership of top executives as well as the effort of subordinates that attends such leadership. "It appears that executives who seek profit too intently are not rewarded with their desired outcome" (de Luque et al., 2008: 646).

This seemingly paradoxical conclusion can be drawn from several theoretical and empirical sources. One theoretical point here is that firm-stakeholder relationships based on mutual trust are difficult to sustain when a firm is dedicated only to generating wealth for its shareholders. Sooner or later, the interests of shareholders and those of other stakeholders will come into conflict, and SWM-oriented managers are likely to make decisions that threaten trust and, hence, the dynamic efficiencies that depend on trust.

Three lines of inquiry highlight the economic value of trust in firm-stakeholder relationships. First, as argued by Jones (1995), trusting relationships between the 
firm and its stakeholders lead to reduced agency costs, transaction costs, and team production costs (see also Blair \& Stout, 1999). Similarly, drawing on arguments about how trusting relationships with stakeholders reduce transaction costs, Barney and Hansen (1994) argue that trust can be a rare, valuable, and inimitable firm resource, and thus can be a source of sustained competitive advantage. Empirical work supports these transactions cost claims. Zaheer, McEvily, and Perrone (1998) find that buyers in the electrical equipment manufacturing industry report lower negotiation costs, less conflict, and better overall performance-a combination of price, timeliness, and quality — when there is a high level of inter-organizational trust between firms. Dyer and Chu (2003) showed that transactions costs were some five times higher for an automotive supplier's least trusted customer as compared to its most trusted customer.

Dyer and Hatch (2006) show how Toyota, using the same suppliers as American automakers, manages to develop the kind of close, trusting relationships that speed up supplier knowledge, ultimately resulting in much lower defect rates. Finally, Uzzi's (1996, 1997) detailed analysis of manufacturer/designer relations in the "better dress" sector of New York's apparel industry found evidence of two types of ties between firms - arm's length ties (market relationships) and embedded ties (close or special relationships). Embedded ties were less common, but were more critical to the firm's business volume and success (Uzzi, 1996). Embedded ties were characterized by "trust, fine-grained information transfer, and joint problem-solving arrangements" (Uzzi, 1997: 42), but trust was their "primary feature." Trust, which Uzzi views as a decision heuristic, accelerated decision-making, economized on cognitive resources, and enhanced access to "privileged and difficult-to-price resources that enhance competitiveness" (Uzzi 1997: 43). The quality of information exchanged tended to be more detailed, tacit, and holistic, and hence, more useful in promoting learning. In particular, the informal "market research" passed on to designers made it easier to bring new items to market quickly and smoothly.

A study by Browning, Beyer, and Shetler (1995) highlights the benefits of unselfish behavior in the context of a highly successful manufacturing technology consortium (SEMATECH). The project initially featured "private agendas, new faces, and an equivocal structure," but evolved into a "moral community in which individuals and firms made contributions to the industry without regard for immediate and specific payback" (Browning et al., 1995: 125, 113). It is doubtful that the behavior prescribed by SWM could have achieved this favorable result. A number of other studies report similar effects (Child \& Möllering, 2003; Dore, 1983; Doz, 1996; Inkpen \& Currall, 2004; Uzzi, 1996). Thus there is ample reason to believe that firms that engage their stakeholders in relationships that transcend arms-length ties, and are instead embedded in a moral framework of mutual trust, may be able to do a better job at creating and delivering the products that the market will reward.

Second, firm-stakeholder relationships based on trust may facilitate the effective transfer of valuable and sensitive knowledge. Knowledge, in comparison to other types of assets, is relatively easily appropriated and used by others without compensation and is, before it is combined with other capabilities, of indeterminate value (Grant, 1996). Once disclosed, knowledge can often be exploited by others without 
compensation. Furthermore, because knowledge may only be useful when combined with other capabilities - such as the manufacturing expertise or distribution chains of other firms - neither the value of the combined capacities nor the contributions of individual partners can be known ex ante. Thus, creating and sustaining environments in which: (1) each party can contribute what they know without fear of being exploited; and (2) neither party requires an elaborate written contract before the fact, will require substantial mutual trust (Kogut \& Zander, 1996). Shedding light on the micro-level dynamics of this effect in a fascinating laboratory study, Tinsley, O'Connor, and Sullivan (2002) show that a reputation for being a "tough" negotiator decreases one's ability to uncover integrative bargaining opportunities because the other party is afraid to share information.

In addition, a firm with a reputation for prosocial behavior may increase efficiency by engendering greater motivation to contribute to the firm on the part of stakeholders (Hosmer, 1994). Indeed, empirical work by Cullen, Parboteeah, and Victor (2003) found that benevolent and principled organizational climates increased commitment among managers ${ }^{10}$ while egoistic climates decreased commitment. Similarly, Turban and Greening (1997) found that firms with greater commitments to stakeholders, measured as higher levels of corporate social performance, are more attractive to job applicants.

Ethically principled firms can motivate increased contributions from other stakeholders besides employees. Surveys reveal that consumers place a high value on the social responsibility of firms, with results indicating that a majority of consumers are willing to pay a 10 percent premium for their products, and that 78 percent weigh a company's social reputation when making buying decisions (Cone/Roper Study, 2004; see also Mohr, Webb, \& Harris, 2001). Thus, there is good reason to suspect that explicit managerial emphasis on "the bottom line"-i.e., shareholder wealth - may undermine the commitment and motivation of stakeholders and actually reduce profits. ${ }^{11}$

Firms that are genuinely committed to the welfare of their stakeholders beyond what is prescribed for instrumental reasons are called moralist firms in the typology developed by Jones, Felps, and Bigley (2007). Through the three mechanisms of less costly coordination, improved learning, and enhanced motivation, these moralist firms may be able to form more efficient, effective, and stable relationships with stakeholders, and consequently, to create greater wealth. In short, it has been argued that an intrinsic regard for stakeholders allows for an integrative brand of relating that expands the "size of the economic pie." In contrast, the single-minded pursuit of shareholder wealth tends to preclude taking advantages of such efficiencies. As such, the claim that pursuing SWM always increases firm efficiency is of dubious validity. There are often better ways to improve firm profitability.

Efficient Firms and Economic Welfare

Even if SWM had been found to be tightly linked to economic efficiency at the firm level, firm level efficiency does not always lead to greater aggregate economic wealth. In particular, negative externalities, situations in which firms do not bear the full cost of their decisions, thus imposing costs on others, occur with some frequency. Many 
actions that increase firm profitability harm other stakeholders. For example, a firm that dumps hazardous waste into a landfill to avoid treatment costs may improve its own efficiency, but it simultaneously imposes economic and/or intangible and unrecorded costs on others. ${ }^{12}$ Nevertheless, it is common for economists to equate firm-level efficiency and aggregate economic wealth. What may have happened in this situation is that the insights of Kaldor (1939) have not been fully developed. What is known as Kaldor-Hicks efficiency was originally presented as a refinement of Pareto efficiency. Pareto efficiency states that economic actions should be taken as long as at least one party is made better off without making any other party worse off. Noting that Pareto efficiency was applicable only to circumstances in which no one was made worse off, Kaldor (1939) added the proviso that efficiency could still be achieved if losers could hypothetically be compensated enough to make them whole without fully depleting the benefits accruing to the winners. ${ }^{13}$ Given that actual compensation of losers was not a serious part of the Kaldor-Hicks dialogue, it is not surprising that little emphasis is placed on the harm caused by externalities in aggregate economic indicators. Many economists, including Jensen (2002), concede the dubious social welfare implications of negative externalities resulting from decisions that profit individual firms but harm other parties within society. He admits that "[w]hen monopolies or externalities exist, the value-maximizing criterion does not maximize social welfare" (Jensen, 2002: 239). In sum, the link between economic efficiency at the firm level and economic welfare at the societal level is seriously weakened by the obvious presence of externalities.

Another case in point stems from the parable of the "tragedy of the commons" (Hardin, 1968). Although originally applied to privately-owned cattle grazing on a commonly-owned pasture, the "tragedy" is that rational self-interested behavior on the part of individuals can have devastating consequences for their collective interests. Situations analogous to the cattle/pasture example arise in other economic domains as well. For example, although efficient individual fisher(wo)men will catch as many fish as they can as fast as they can, over time the fishing grounds will be depleted and aggregate economic welfare will be harmed. And although some controversy still surrounds the issue, mounting scientific evidence suggests that the release of carbon dioxide and other greenhouse gases into the atmosphere by individual companies/nations will eventually lead to global warming with serious and widespread negative economic consequences (Stern, 2007). In conclusion, the link between economic efficiency at the firm level and economic welfare at the societal level is seriously weakened by the obvious presence of externalities and tragedy of the commons situations.

Another possible distortion of the efficient firm-to-economic welfare equation is the significant rise in the proportion of economic activity devoted to what has been called "guard labor" (Jayadev \& Bowles, 2006). According to these authors, Pareto (1971) was the first to observe that human beings can direct their economic efforts in one of two directions: the "production or transformation of economic goods" or the "appropriation of goods produced by others." According to the nomenclature of Jayadev and Bowles (2006), guard labor is that portion of the labor force- "the police, private security guards, and military personnel, and others"- that attempts 
to prevent this appropriation. By the estimates of these scholars, guard labor currently constitutes about 25 percent of the total labor force in the USA. The US Labor Department estimated that private security guards would outnumber high school teachers by $2012 .{ }^{14}$ In most calculations of aggregate economic welfare, guard labor companies certainly add to the total output of the economy, but one is certainly entitled to question the magnitude of their addition to economic welfare. ${ }^{15}$ The question that we must answer in this context is: Are societies really economically better off if they devote an increasing proportion of their resources to preventing the appropriation, rather than the production, of goods and services? Frank's (1999) work suggests that a similar question could be asked in the context of burglar alarms, drug counseling services, and pollution control equipment. Again, firm level efficiency appears to be very different than efficient use of resources by society as a whole.

Economic Welfare and Human Happiness

Beginning with Adam Smith, Thomas Malthus, and John Stuart Mill, the raison d'être of economic activity was thought to be the promotion of human happiness, a touchstone of utilitarian moral philosophy (Audi, 2007; Lane, 2000). In the words of legal scholar Richard Posner:

Utilitarianism . . . holds that the moral worth of an action (or of a practice, institution, law, etc.) is to be judged by its effect in promoting happiness- 'the surplus of pleasure over pain'-aggregated across all of the inhabitants . . of "society." (Posner, 1979: 104).

Smith, Malthus, and Mill were concerned primarily with the role of economic wealth in improving human happiness, an important consideration in an era of relative scarcity. Nonetheless, each of these scholars realized that wealth and happiness were not identical phenomena. Wealth was seen as a means to happiness, not an end in itself, a view shared by a number of contemporary scholars-e.g., Audi, 2007; Carter, 1968; Hicks, 1939; Kagan, 1991; Lane, 2000; Singer, 2011; and Kaplow and Shavell, 2001.

In 1948, Paul Samuelson, confronting the difficulties of measuring utility, argued that "revealed preferences" (prices paid by rational people in the voluntary transactions that characterize market capitalism) should replace the subjective and intangible notion of happiness as the focal concern of the discipline. This modification greatly simplified the study of economics by creating more theoretically precise and empirically tractable variables. As the twentieth century progressed, few influential economists concerned themselves with the distinction between wealth and happiness, focusing almost exclusively on the former. ${ }^{16}$ However, the application of this insight also distorted the moral foundation of economic activity by making economic wealth, formerly a means to an end (happiness), the desired end itself.

In addition, if preferences are revealed primarily through market purchases, one result of Samuelson's "insight" is that the utility/value of goods and services is determined by what customers are willing to pay for them. Since markets serve an important allocative function-i.e., directing resources to the production of goods and services that people want to buy - the utility of goods and services preferred by people with ample amounts of money will be recorded far more often than the utility 
of those with little money. For example, if we grant that the happiness generated by the purchase of $\$ 4$ sandwiches by twenty-five destitute people may be greater than that generated by the purchase of a $\$ 100$ meal by one prosperous person, it becomes clear that economic welfare and happiness are very different concepts. Indeed, the semantic conflation of dollars and utility by economists should be kept distinct from the moral philosophy of utilitarianism. Blanchflower and Oswald extend this thinking by suggesting that "national happiness is an improvement over GDP" as a social indicator (2011: 11), recalling classic utilitarianism in the process. ${ }^{17}$

Furthermore, in recent years, scholars have begun to question the assumption of a strong positive relationship between material wealth and human happiness. Indeed, a growing body of evidence suggests that increased wealth does not necessarily lead to increased happiness at either the individual or societal levels. This evidence falls into three categories: cross-national, within-nation differences among individuals, and within-nation changes over time.

First, recent research on cross-national differences does in fact indicate a positive correlation between wealth and happiness (Diener \& Biswas-Diener, 2002). That is, the average person in a wealthier country will score higher on objective/ physiological and subjective/self-reported measures of well-being. Moreover, these relationships are moderate in strength with correlations around 0.30 (Diener, Suh, Lucas, \& Smith, 1999). However, a closer inspection of the data reveals that the relationship between national wealth and national well-being is asymptotic; as a country moves up the prosperity ladder, additional increases in national wealth tend to buy less and less national happiness (Diener \& Biswas-Diener, 2002; Frey \& Stutzer, 2002; Helliwell, 2003; Schyns, 2003). For example, while inhabitants of a second-world country-e.g., Colombia-are likely to be much happier than those in a third world country-e.g., Albania — they will be, on average, only a little less happy than those in a first world country-e.g., the United States. ${ }^{18}$ What is especially interesting about this curvilinear relationship is just how quickly_around $\$ 10,000$ US per capita-income ceases to be an important contributor to well-being (Frey \& Stutzer, 2002). Diener and Seligman (2004), examining only nations with per capita GDP above $\$ 10,000$, found that income/per capita GDP explains a paltry 1.6 percent of the variance in national happiness, measured as average life satisfaction. Moreover, Helliwell and Huang (2008) argue that even in poor countries, the wealth to happiness relationship is considerably weakened when the effects of political variables such as corruption, civil liberties, and political stability are statistically taken into account.

Second, findings involving within-nation differences among individuals are remarkably consistent with these cross-national data. Here again, there seems to be a diminishing returns relationship, where additional wealth is a key contributor to well-being among the poor, but has comparatively little impact on those already economically comfortable (Diener et al., 1999).

Finally, evidence of changes within countries as they become more prosperous also casts doubt on the assumed close link between wealth and happiness. Frank (1999) reports that the number of Americans responding that they were very happy declined from 1972 to 1991 despite a 39 percent increase in inflation-adjusted per 
capita income. Similarly, the mean happiness in Japan remained constant from 1958 to 1986 despite a five-fold increase in real per capita income over the twentyeight-year period. Equivalent results obtained in other countries; large increases in national wealth were accompanied by little or no change in measures of national well-being (Diener \& Biswas-Diener, 2002; Easterbrook, 2003; Oswald, 1997). Within-nation comparisons over time are consistent with both cross-national data and within-nation differences among individuals; once a certain threshold is reached, greater wealth buys very little additional happiness.

A final, and idiosyncratic, bit of evidence comes in the form of happiness data from lottery winners who have become a great deal wealthier in a very short period of time. Brickman, Coates, and Janoff-Bulman (1978) found that, although these big winners were understandably much happier immediately after their windfall, the effects did not endure and, in some ways, years later they were less happy than before.

There are two complementary explanations for these effects. First, as people become more prosperous, the material goods that wealth provides are no longer the scarce resource in their lives. Thus, wealth provides diminishing utility as it becomes more abundant. Second, as people move up the prosperity ladder, their financial aspirations quickly come to outstrip their financial realities (Easterlin, 2001; Frey \& Stutzer, 2002; Graham \& Pettinato, 2002). In an ironic twist, as people become wealthier, they have more opportunity to observe and compare themselves to those who are wealthier still, and if they believe that wealth is very important in life, they tend to become dissatisfied with their lives (Frank, 1999; Hagerty, 2000). Indeed, materialism itself has been shown to be a largely dysfunctional aim, associated with lower self-esteem, greater narcissism, less empathy, less intrinsic motivation, deteriorated social relationships, and worse overall subjective well-being (Kasser, Ryan, Couchman, \& Sheldon, 2004; Nickerson, Schwarz, Diener, \& Kahneman, 2003).

Therefore, with the only meaningful positive relationship between wealth and happiness being confined to steep increases at the low end of the economic spectrum, we must ask how much aggregate happiness is enhanced by aggregate wealth increases, especially if such increases are concentrated at the upper end of the economic spectrum, as they increasingly are in the US (Krugman, 2007). Yet another link in the chain of arguments leading from SWM to improved social welfare has been shown to be empirically weak.

SWM to Social Welfare: The Sequential Argument Reviewed

In summary, four conclusions are relevant: (1) many markets are not sufficiently competitive, (2) maximizing shareholder wealth is not always the best way to achieve firm efficiency, (3) increases in efficiency may not increase aggregate economic welfare, and (4) greater economic welfare is only weakly linked to greater human happiness. The theoretical chain connecting SWM to improved social welfare has substantial weaknesses at every link.

These weaknesses are especially problematic when one considers that the argument is multiplicative. If any link in the causal chain is completely absent, then there is no connection whatsoever between SWM and social welfare based on this formulation. More generously, if each of the causal links were to explain, say, 
20 percent of the variance in the criterion, then the overall relationship would be extremely weak-i.e., $0.20 \times 0.20 \times 0.20$ equals 0.8 percent of the total variance. Under either of these scenarios, the argument that SWM is an essential part of a path to maximal social welfare is seriously compromised.

However, we are mindful of Kuhn's (1962) admonition that entrenched theory is rarely abandoned, even in the face of disconfirming evidence, unless more compelling theory is advanced to take its place. As we noted at the outset, our effort to provide a compelling alternative to SWM will be presented in the second of two articles. However, in view of our utilitarian/social welfare analysis of SWM in this article, we offer a preview of the preferred corporate objective that we advance and defend in detail in the second article.

\section{NORMATIVE STAKEHOLDER THEORY AND SOCIAL WELFARE}

It will come as no surprise that our preferred alternative to SWM is a variant of normative stakeholder theory. Furthermore, in view of our utilitarian/social welfare critique of SWM, we adopt a set of similar utilitarian criteria for our assessment of normative stakeholder theory. More specifically, we advance four conceptual propositions, based on our four-stage analysis of SWM, to guide our inquiry.

Criterion 1) All else being equal, corporate objectives based on realistic assessments of the nature of economic competition will provide greater social welfare than those based on unrealistic assumptions-e.g., perfect competition.

Comparative assessment: Unlike SWM, which is highly dependent on the existence of perfectly competitive (and unattainable) markets, normative stakeholder theory does not depend on any unrealistic market assumptions.

Criterion 2) All else being equal, corporate objectives that allow/encourage efficiencies based on mutually trusting firm-stakeholder relationships will provide greater social welfare than those that assume that efficient firm behavior depends only on the pursuit of self interest.

Comparative assessment: SWM directs managers to pursue the interests of the firm directly and is not compatible with strategies that require the suspension of self-interested behavior in favor of trusting, trustworthy, and cooperative behavior. Because normative stakeholder theory is inherently concerned with the well-being of all stakeholders, it encourages the trusting, trustworthy, and cooperative behavior upon which some forms of profitable operations depend.

Criterion 3) All else being equal, corporate objectives will provide greater social welfare to the extent that they explicitly account for the costs of negative externalities.

Comparative assessment: Negative externalities that are not legally prohibited are allowed under SWM. Normative stakeholder theory explicitly admonishes managers to include the legitimate interests of all corporate stakeholders in their decision making deliberations. 
Criterion 4) All else being equal, corporate objectives that focus directly on the well-being of legitimate corporate constituents will provide greater social welfare than those that simply equate economic and social welfare.

Comparative assessment: SWM is part of a set of institutions concerned only with increasing aggregate economic welfare, despite mounting evidence that economic welfare and social welfare (aggregate happiness) are not closely linked. Many currently available forms of normative stakeholder theory focus on stakeholder "interests," without specifying whether those interests are elements of economic welfare or social welfare. Importantly, nothing within the normative stakeholder theory framework precludes a direct focus on social welfare/aggregate happiness.

And to sum up:

Criterion 5) All else being equal, corporate objectives that apply an act utilitarian logic that focuses directly on the welfare of legitimate corporate constituents will provide greater social welfare than those that approach social welfare through an indirect rule utilitarian logic that depends on several dubious conceptual and empirical propositions.

Comparative assessment: As discussed at length above, the link between social welfare and SWM depends for its persuasive power on a sequence of four propositions of dubious validity. Normative stakeholder theory, because its moral foundation is act utilitarianism, is capable of focusing directly the desired end of economic activity-aggregate social welfare.

On the basis of this set of conceptual propositions, we conclude that some variant of normative stakeholder theory will be capable of better enhancing social welfare than SWM. Indeed, in the second article in this sequence, we will advance and defend a corporate objective that is a variant of normative stakeholder theory that we believe is superior to SWM.

\section{THEORETICAL CONNECTIONS}

SWM is clearly a vital part of a system of institutional arrangements that frame market capitalism in the US (Meyer \& Höllerer, 2010). Anyone seeking to reform the system in anything approaching a comprehensive way must acknowledge the systemic requirements of their proposed reforms. In general, the current set of institutions is based on what has been called the "separate magisteria" argumentbusiness is concerned with economic matters; governments are concerned with social welfare matters. Governments, of course, can guide and constrain business through the application of public policy, but business must maximize profits without regard for social issues. The assumption is that the economic system will produce maximal social welfare if market forces, acting through SWM and constrained by governmental institutions, are allowed to guide corporations to optimal decisions. If reform is needed, this model instructs reformers to change the institutions surrounding SWM to allow profit maximizing behavior to better produce social welfare. 
We have argued that this approach is flawed for two reasons. First, some very significant economic and social problems - recent, recurring, or persistent-seem to be related to the set of institutions currently in place. Second, reform of the "constraining" governmental institutions has, for political and theoretical reasons, a long history marked by a mixture of success and failure. Nonetheless, sufficient reform of the institutions surrounding the SWM mandate would be a truly daunting task for both political (corporate political power) and conceptual ("theory of the second best") reasons.

In addition, several scholars have noted the overly pessimistic assumptions about human behavior-i.e., self-interest, opportunism - that underlie our economic and management theories-i.e., agency theory and transactions costs economics. They argue that these theories have the effect of legitimizing and promoting the very behavior that the theories are employed to constrain. We address both of these concerns.

According to institutional theorist W. R. Scott (1995), there are three "pillars" on which institutions stand-regulative (coercive forces), normative (normative standards), and cultural-cognitive (imitation of others). By taking a normative approach to economic reform, we: (a) provide a complementary alternative to those seeking to promote social welfare through regulative/coercive means; and (b) avoid making excessively pessimistic assumptions about managerial motives. Our proposed alternative corporate objective, suggested in this article and formally presented in detail and defended in the second article, sidesteps both the monumental regulative task of reforming the institutions that surround SWM and the assumption that constraining bad behavioral instincts is the only way to guide corporate behavior. Indeed, we place responsibility for the economic aspects of social welfare squarely on the shoulders of corporate managers and, by urging them to concern themselves with the well-being of a group of stakeholders that includes (but is not limited to) shareholders, assume that their better instincts will prevail.

\section{SUMMARY AND CONCLUSIONS}

In this, the first of two articles advocating and justifying a change in the normative objective of corporate governance, we provided a compelling argument that shareholder wealth maximization is not a good way to promote social welfare. In this process, we examined a sequence of four interconnected claims on which we believe the moral justification of SWM rests. We found each of these claims to be conceptually and/or empirically weak and concluded that the overall logic of the normative argument linking SWM to social welfare is of dubious validity. To the best of our knowledge, this utilitarian/social welfare critique of SWM is unique in the literatures of management and economics. In addition, within this critique, we employed a novel technique called positive-normative triangulation (e.g., Donaldson, 2007), which uses a combination of positive evidence and normative concepts, to shed light on an important normative question.

Although we have proposed a significant revision to the objective of corporation governance, this effort should not be thought of as a product of radical thinking, but as a natural response to changes in the economy and society in general. The 
production of goods and services in the twenty-first century is a much more complicated affair than the making of pins in Adam Smith's 1776 example. Corporations, involving numerous complex and interdependent activities, have replaced many functions formerly performed through simple market exchanges (Chandler, 1977). The corporate structure allows cooperation to supplement, and sometimes replace, the self-interested behavior often required of market participants. Yet, the self-interest of Adam Smith's butcher, baker, and brewer continues to be the guiding purpose for many contemporary managers, even though today's complex and dynamic economies often require firms to adhere to the moral norms of honesty, loyalty, compassion, and fair play (Donaldson, 1999; Hendry, 2001, 2004)

Moreover, citizens of western industrialized countries are increasingly living in affluent societies in which many people's basic material needs have already been met (Galbraith, 1958; Offer, 2006). While there are still pockets of poverty in these countries, they are quite prosperous in the aggregate. As Carter noted over forty years ago, "[t]he richer a country becomes, the less need it has to be ruled by economic thinking" (Carter, 1968: 168). By casting serious doubt on one of market capitalism's most entrenched institutions — shareholder wealth maximization-we hope to alter that way of thinking.

\section{NOTES}

We gratefully acknowledge constructive comments made on earlier versions of this article by Robert Phillips, Eliza Byington, and Judith Edwards. Thomas Jones would like to thank the Darden School at the University of Virginia for support he received as the Rust Visiting Professor, which allowed him to develop and refine this article. Will Felps would like to thank participants at an internal research seminar at the Rotterdam School of Management, where he worked while this article was being developed. Any errors are our own.

1. The authors contributed equally to this article.

2. Although best known for his "invisible hand" economic theory, Smith was also a moral philosopher and was acutely aware of the importance of "moral sentiments" in a healthy society.

3. Some scholars acknowledge the impossibility of maximizing either shareholder wealth or profits. Friedman (1970) used the term "increase profits" while Jensen (2002) prefers "value seeking." Neither, however, suggests that obligations are owed to any constituent group other than shareholders.

4. An interesting and detailed account of this process can be found in An Engine, Not a Camera (MacKenzie, 2006).

5. Individual corporations are certainly not striving to maximize social welfare; they are striving to maximize shareholder welfare. It is through the economic institutions of market capitalism (including SWM), a set of rules, that social welfare is pursued.

6. In addition to being a theory of management, stakeholder theory is considered by many to have three distinct themes - descriptive, instrumental, and normative (Donaldson \& Preston, 1995). We are concerned only with the normative variant-i.e., what managers should do.

7. For a fascinating narrative account of this event, see A Civil Action by Jonathan Harr (1996).

8. Causal "arrows" were found in both directions. Better CSP leads to improved FP and better FP leads to improved CSP_a "virtuous circle."

9. Of course, the prisoner's dilemma from game theory is an obvious example of short-term, selfinterested strategies undermining more productive longer term, cooperative strategies. A rational player will always defect, but if both players are rational, both will defect, leading to poor payoffs for both players.

10. Benevolent climates also increased commitment for line personnel in addition to managers.

11. Jensen and others (e.g., Keay, 2012; Matheson \& Olson, 1991) have endorsed an "enlightened" version of wealth maximization that allows managers to ignore share prices in the short-run in order to invest in close relationships with other stakeholders, a practice expected to pay off in the long-run for shareholders. 
Stakeholder theorists call this instrumental stakeholder theory (Donaldson \& Preston, 1995; Jones, 1995). What Jensen and others who advocate this approach do not consider is that it is difficult to maintain the trust and cooperation required for good firm-stakeholder relations when a firm's fundamental loyalties are to shareholders. According to Frank (1988), authentic behavior is difficult to "fake" and inauthentic behavior may not achieve the desired ends; in other words, it is difficult to be instrumentally moral (see also Hosmer, 1994; Jones, 1995).

12. Ironically, if another company is created to dispose of toxic waste, measured economic welfare-in the form of GDP-may increase, even though wealth has been destroyed.

13. Hicks (1939) added the insight that efficiency could also be achieved if losers could not afford to pay/bribe the winners to prevent them from carrying out the proposed action.

14. To the best of our knowledge, actual data for 2012 have yet to appear.

15. More specifically, consider the following questions. Is economic welfare really the same if firms must spend 10 percent, rather than 5 percent, of their pretax income on guard labor? Or, would most people prefer to freely spend $\$ 2000$ on a home entertainment center rather than compelled to spend $\$ 2000$ on an elaborate security system?

16. This equating of utility and wealth has not been limited to economic scholarship. Indeed, this logic has become common throughout the chambers of law, politics, and the boardrooms of many large firms (Ghoshal, 2005).

17. Interestingly, contemporary surveys have shown that human beings side with the classicists, regarding happiness as more important than wealth in their assessments of quality of life (Diener, 2000; King \& Napa, 1998).

18. For country level happiness scores, see Marks, Abdallah, Simms, and Thompson (2006).

\section{REFERENCES}

Agle, B. R., Donaldson, T., Freeman, R. E., Jensen, M. C., Mitchell, R. K., \& Wood, D. J. 2008. Dialogue: Toward a superior stakeholder theory. Business Ethics Quarterly, 18: 153-90. http://dx.doi.org/10.5840/beq200818214

Alexander, L. 1999. Determining board effectiveness. New York: Conference Board Research Reports.

Arnott, R., Greenwald, B., Kanbur, R., \& Nalebuff, B. (Eds.). 2003. Economics for an imperfect world: Essays in honor of Joseph E. Stiglitz. Cambridge, Mass.: MIT Press.

Audi, R. 2007. Can utilitarianism be distributive? Maximization and distribution as criteria in managerial decisions. Business Ethics Quarterly, 17(4): 593-611. http://dx.doi.org/10.5840/beq20071741

Bainbridge, S. M. 1993. In defense of the shareholder wealth maximization norm: A reply to Professor Green. Washington and Lee Law Review, 50: 1423-48.

2002. Director primacy: The means and ends of corporate governance. Northwestern University Law Review, 97: 547.

Barney, J. B., \& Hansen, M. H. 1994. Trustworthiness as a source of competitive advantage. Strategic Management Journal, 15: 175-90.

http://dx.doi.org/10.1002/smj.4250150912

Baumol, W. J., Panzar, J. C., \& Willig, R. D. 1982. Contestable markets and the theory of industry structure. New York: Harcourt Brace Jovanovich.

Beekun, R. I., \& Badawi, J. A. 2005. Balancing ethical responsibility among multiple organizational stakeholders: The Islamic perspective. Journal of Business Ethics, 60(2): 131-45. http://dx.doi.org/10.1007/s10551-004-8204-5 
Berle, A. A. 1931. Corporate powers as powers in trust. Harvard Law Review, 44: 104974. http://dx.doi.org/10.2307/1331341

Blair, M. M., \& Stout, L. A. 1999. A team production theory of corporate law. Virginia Law Review, 85: 247-303. http://dx.doi.org/10.2307/1073662

Blanchflower, D. G., \& Oswald, A. J. 2011. International happiness: A new view on the measure of performance. Academy of Management Perspectives, 25: 6-22. http://dx.doi.org/10.5465/AMP.2011.59198445

Boatright, J. R. 1994. Fiduciary duties and the shareholder-management relation: Or, what's so special about shareholders? Business Ethics Quarterly, 4(4): 393-407. http://dx.doi.org/10.2307/3857339

. 2006. What's wrong — and what's right—with stakeholder management. Journal of Private Enterprise, 21(2): 106-30.

Bosse, D. A., Phillips, R. A., \& Harrison, J. S. 2009. Stakeholders, reciprocity, and firm performance. Strategic Management Journal, 30: 447-56.

http://dx.doi.org/10.1002/smj.743

Bowen, H. R. 1953. Social responsibilities of the businessman. New York: Harper.

Bowie, N. E. 1998. A Kantian theory of capitalism. Business Ethics Quarterly, 1: 37-60.

Brickman, P., Coates, D., \& Janoff-Bulman, R. 1978. Lottery winners and accident victims: Is happiness relative? Journal of Personality and Social Psychology, 36(8): 917-27. http://dx.doi.org/10.1037/0022-3514.36.8.917

Browning, L. D., Beyer, J. M., \& Shetler, J. C. 1995. Building cooperation in a competitive industry. Academy of Management Journal, 38: 113-51.

http://dx.doi.org/10.2307/256730

Carter, C. F. 1968. Wealth: An essay on the purposes of economics. London: Watts.

Chandler, A. D. 1977. The visible hand: The managerial revolution in American business. Cambridge, Mass.: Harvard University Press.

Child, J., \& Möllering, G. 2003. Contextual confidence and active trust development in the Chinese business environment. Organization Science, 14(1): 69-80. http://dx.doi.org/10.1287/orsc.14.1.69.12813

Comanor, W. S. 1967. Market structure, product differentiation, and industrial research. The Quarterly Journal of Economics, 81(4): 639-57. http://dx.doi.org/10.2307/1885583

Cone/Roper Study. 2004. A benchmark survey of consumer awareness and attitudes towards cause related marketing. Boston: Cone Communications.

Cullen, J. B., Parboteeah, K. P., \& Victor, B. 2003. The effects of ethical climates on organizational commitment: A two-study analysis. Journal of Business Ethics, 46(2): 127-41. http://dx.doi.org/10.1023/A:1025089819456

Davis, K. 1973. The case for and against business assumption of social responsibilities. Academy of Management Journal, 16: 312-22. http://dx.doi.org/10.2307/255331

de Luque, D., Washburn, N. T., Waldman, D. A., \& House, R. J. 2008. Unrequited profit: How stakeholder and economic values relate to subordinates' perceptions of leadership and firm performance. Administrative Science Quarterly, 53: 626-54. http://dx.doi.org/10.2189/asqu.53.4.626 
Demsetz, H. 1975. Two systems of belief about monopoly. In H. Goldschmid, H. M. Mann, \& J. E. Weston (Eds.), Industrial concentration: The new learning: 164-84. Boston: Little, Brown.

Diener, E. 2000. Subjective well-being: The science of happiness and a proposal for a national index. American Psychologist, 55: 34-43. http://dx.doi.org/10.1037/0003-066X.55.1.34

Diener, E., \& Biswas-Diener, R. 2002. Will money increase subjective well-being? A literature review and guide to needed research. Social Indicators Research, 119-69. http://dx.doi.org/10.1023/A:1014411319119

Diener, E., \& Seligman, M. E. P. 2004. Beyond money: Towards an economy of wellbeing. Psychological Science in the Public Interest, 5(1): 1-31. http://dx.doi.org/10.1111/j.0963-7214.2004.00501001.x

Diener, E., Suh, E. M., Lucas, R. E., \& Smith, H. E. 1999. Subjective well-being: Three decades of progress. Psychological Bulletin, 125: 276-302. http://dx.doi.org/10.1037/0033-2909.125.2.276

Dodd, E. M. 1932. For whom are corporate managers trustees? Harvard Law Review, 45: 1145-63. http://dx.doi.org/10.2307/1331697

Donaldson, T. 1999. Making stakeholder theory whole. Academy of Management Review, 24: 237-41. http://dx.doi.org/10.2307/259079

. 2006. Squaring the circle: Superimposing the normative on the empirical. Symposium presentation at the annual meeting of the Academy of Management Atlanta.

2007. Should business be moral? Zeitschrift für Wirtschafts- und Unternehmensethik. Mering, 8(3): 270-75.

2008. Pre-constructing opposites: Normative triangulation. Symposium presentation at the annual meeting of the Academy of Management Anaheim.

2012. The epistemic fault line in corporate governance. Academy of Management Review, 37(2): 256-71. http://dx.doi.org/10.5465/amr.2010.0407

Donaldson, T., \& Dunfee, T. W. 1994. Towards a unified conception of business ethics: Integrative social contracts theory. Academy of Management Review, 19: 252-84.

Donaldson, T., \& Preston, L. E. 1995. The stakeholder theory of the corporation: Concepts, evidence, and implications. Academy of Management Review, 20: 65-91.

Dore, R. 1983. Goodwill and the spirit of market capitalism. British Journal of Sociology, 34: 459-82. http://dx.doi.org/10.2307/590932

Doz, Y. L. 1996. The evolution of cooperation in strategic alliances: Initial conditions or learning processes? Strategic Management Journal, 17: 55-83. http://dx.doi.org/10.1002/smj.4250171006

Dyer, J. H., \& Chu, W. 2003. The role of trustworthiness in reducing transaction costs and improving performance: Empirical evidence from the United States, Japan, and Korea. Organization Science, 14(1): 57-68.

http://dx.doi.org/10.1287/orsc.14.1.57.12806 
Dyer, J. H., \& Hatch, N. 2006. Relation-specific capabilities and barriers to knowledge transfers: Creating advantage through network relationships. Strategic Management Journal, 27: 701-19. http://dx.doi.org/10.1002/smj.543

Easterbrook, G. 2003. The progress paradox: How life gets better while people feel worse. New York: Random House.

Easterlin, R. A. 2001. Income and happiness: Towards a unified theory. The Economic Journal, 111(473): 465-84. http://dx.doi.org/10.1111/1468-0297.00646

Ehrlich, C. 2005. Is business ethics necessary? DePaul Business \& Commercial Law Journal, 4: 55-86.

Erhard, W., Jensen, M. C., \& Zaffron., S. 2008. Integrity: A positive model that incorporates the normative phenomena of morality, ethics and legality. Working Paper. No. 06-11, http://ssrn.com/abstract=920625. Harvard Business School NOM.

Evan, W. M., \& Freeman, R. E. 1993. A stakeholder theory of the modern corporation: Kantian capitalism. In T. L. Beauchamp \& N. E. Bowie (Eds.), Ethical theory and business: 97-106. Englewood Cliffs, N.J.: Prentice Hall.

Fannon, I. L. 2003. Working within two kinds of capitalism: Corporate governance and employee stakeholding-US and EC perspectives. Oxford: Hart Publishing.

Ferraro, F., Pfeffer, J., \& Sutton, R. I. 2005. Economic language and assumptions: How theories can become self-fulfilling. Academy of Management Review, 30(1): 8-24. http://dx.doi.org/10.5465/AMR.2005.15281412

Frank, B., \& Schulze, G. G. 2000. Does economics make citizens corrupt? Journal of Economic Behavior \& Organization, 43(1): 101-13. http://dx.doi.org/10.1016/S0167-2681(00)00111-6

Frank, R. H. 1988. Passions within reason: The strategic role of the emotions. New York: W. W. Norton \& Co.

1999. Luxury fever: Why money fails to satisfy in an era of excess. New York: Free Press.

Frank, R. H., Gilovich, T., \& Regan, D. T. 1993. Does studying economics inhibit cooperation? The Journal of Economic Perspectives, 7(2): 159-71. http://dx.doi.org/10.1257/jep.7.2.159

Freeman, R. E., Harrison, J. S., Wicks, A. C., Parmar, B., \& De Colle, S. 2010. Stakeholder theory: The state of the art. Cambridge: Cambridge University Press. http://dx.doi.org/10.1017/CBO9780511815768

Freeman, R. E., Wicks, A. C., \& Parmar, B. 2004. Stakeholder theory and "The corporate objective revisited.” Organization Science, 15: 364-69. http://dx.doi.org/10.1287/ orsc. 1040.0066

Frey, B. S., \& Stutzer, A. 2002. Happiness and economics: How the economy and institutions affect human well-being. Princeton, N.J.: Princeton University Press.

Friedman, M. 1962. Capitalism and freedom. Chicago: University of Chicago Press. 1970. The social responsibility of business is to increase its profits. New York Times Magazine (September 13).

Galbraith, J. K. 1958. The affluent society. Boston: Houghton Mifflin. 
Gale, B. T. 1972. Market share and rate of return. The Review of Economics and Statistics, 54(4): 412. http://dx.doi.org/10.2307/1924568

Ghemawat, P., \& Costa, J. E. R. I. 1993. The organizational tension between static and dynamic efficiency. Strategic Management Journal, 14: 59-73. http://dx.doi.org/10.1002/smj.4250141007

Ghoshal, S. 2005. Bad management theories are destroying good management practices. Academy of Management Learning \& Education, 4(1): 75-91. http://dx.doi.org/10.5465/AMLE.2005.16132558

Ghoshal, S., Bartlett, C. A., \& Moran, P. 1999. A new manifesto for management. MIT Sloan Management Review, 40(3): 9-20.

Ghoshal, S., \& Moran, P. 1996. Bad for practice: A critique of the transaction cost theory. Academy of Management Review, 21: 13-47.

Gordon, J. N. 2007. The rise of independent directors in the United States, 1950-2005: Of shareholder value and stock market prices. Stanford Law Review, 59(6): 1465.

Gould, S. J. 1999. Rocks of ages: Science and religion in the fullness of life. London: Random House.

Graham, C., \& Pettinato, S. 2002. Happiness and hardship: Opportunity and insecurity in new market economies. Washington, D.C.: Brookings Institution Press.

Grant, R. M. 1996. Toward a knowledge-based theory of the firm. Strategic Management Journal, 17: 109-22.

Green, R. M. 1993. Shareholders as stakeholders: Changing metaphors of corporate governance. Washington and Lee Law Review, 50: 1409.

Hagerty, M. R. 2000. Social comparisons of income in one's community: Evidence from national surveys of income and happiness. Journal of Personality and Social Psychology, 78(4): 764-71. http://dx.doi.org/10.1037/0022-3514.78.4.764

Hardin, G. 1968. The tragedy of the commons. Science, 162(3859): 1243-48.

Harr, J. 1996. A civil action. New York: Vintage.

Helliwell, J. F. 2003. How's life? Combining individual and national variables to explain subjective well-being. Economic Modeling, 20: 331-60.

http://dx.doi.org/10.1016/S0264-9993(02)00057-3

Helliwell, J. F., \& Huang, H. 2008. How's your government? International evidence linking good government and well-being. British Journal of Political Science, 38: 595619. http://dx.doi.org/10.1017/S0007123408000306

Henderson, D. 2001. Misguided virtue: False notions of corporate social responsibility. London: Institute of Economic Affairs.

Hendry, J. 2001. Economic contract versus social relationships as a foundation for normative stakeholder theory. Business Ethics: European Review, 10: 223-32. http://dx.doi.org/10.1111/1467-8608.00236

2004. Between enterprise and ethics: Business and management in a bimoral society. Oxford: Oxford University Press.

http://dx.doi.org/10.1093/acprof:oso/9780199268634.001.0001

Hicks, J. R. 1939. The foundations of welfare economics. The Economic Journal, 49(196): 696-712. http://dx.doi.org/10.2307/2225023 
Hillman, A. J., Keim, G. D., \& Schuler, D. 2004. Corporate political activity: A review and research agenda. Journal of Management, 30(6): 837-57.

http://dx.doi.org/10.1016/j.jm.2004.06.003

Hosmer, L. T. 1994. Why be moral? A different rationale for managers. Business Ethics Quarterly, 4: 191-204. http://dx.doi.org/10.2307/3857491

Hosmer, L. T., \& Kiewitz, C. 2005. Organizational justice: A behavioral science concept with critical implications for business ethics and stakeholder theory. Business Ethics Quarterly, 15: 67-91. http://dx.doi.org/10.5840/beq20051513

Inkpen, A. C., \& Currall, S. C. 2004. The coevolution of trust, control, and learning in joint ventures. Organization Science, 15(5): 586-99.

http://dx.doi.org/10.1287/orsc.1040.0079

Jacobson, R. 1992. The "Austrian” school of strategy. Academy of Management Review, 17: 782-807.

Jayadev, A., \& Bowles, S. 2006. Guard labor. Journal of Development Economics, 79(2): 328-48. http://dx.doi.org/10.1016/j.jdeveco.2006.01.009

Jensen, M. C. 2002. Value maximization, stakeholder theory and the corporate objective. Business Ethics Quarterly, 12: 235-56. http://dx.doi.org/10.2307/3857812

Jensen, M. C., \& Meckling, W. H. 1976. Theory of the firm: Managerial behavior, agency costs and ownership structure. Journal of Financial Economics, 3(4): 305-60. http://dx.doi.org/10.1016/0304-405X(76)90026-X

Jones, T. M. 1980. Corporate social responsibility revisited, redefined. California Management Review, 22(3): 59-67. http://dx.doi.org/10.2307/41164877

1995. Instrumental stakeholder theory: A synthesis of ethics and economics. Academy of Management Review, 20: 404-37.

Jones, T. M., Felps, W., \& Bigley, G. A. 2007. Ethical theory and stakeholder-related decisions: The role of stakeholder culture. Academy of Management Review, 32: 137-55. http://dx.doi.org/10.5465/AMR.2007.23463924

Kagan, S. 1991. The limits of morality. Oxford: Clarendon Press. http://dx.doi.org/10.1093/0198239165.001.0001

Kaldor, N. 1939. Welfare propositions in economics and interpersonal comparisons of utility. Economic Journal, 49(195): 549-52. http://dx.doi.org/10.2307/2224835

Kaplow, L., \& Shavell, S. 2001. Fairness versus welfare. Harvard Law Review, 114(4): 961-1388. http://dx.doi.org/10.2307/1342642

Kasser, T., Ryan, R. M., Couchman, C. E., \& Sheldon, K. M. 2004. Materialistic values: Their causes and consequences. In T. Kasser \& A. D. Kanner (Eds.), Psychology and consumer culture: The struggle for a good life in a materialistic world: 1128. Washington, D.C.: American Psychological Association.

Keay, A. 2012. The enlightened shareholder value principle and corporate governance. London: Routledge.

Keynes, J. M. 1936. The general theory of employment, interest and money. London: Macmillan.

King, L. A., \& Napa, C. K. 1998. What makes a life good? Journal of Personality and Social Psychology, 75: 156-65. http://dx.doi.org/10.1037/0022-3514.75.1.156 
Kogut, B., \& Zander, U. 1996. What firms do? Coordination, identity, and learning. Organization Science, 7: 502-18. http://dx.doi.org/10.1287/orsc.7.5.502

Korn/Ferry International. 2000. 27th Annual Board of Directors Study 2000.

Krugman, P. 2007. The conscience of a liberal. New York: W. W. Norton.

Kuhn, T. S. 1962. The structure of scientific revolutions (1st ed.). Chicago: University of Chicago Press.

Kuttner, R. 1999. Everything for sale: The virtues and limits of markets. Chicago: University of Chicago Press.

Lane, R. E. 2000. The loss of happiness in market democracies. New Haven, Conn.: Yale University Press.

Laplume, A. O., Sonpar, K., \& Litz, R. A. 2008. Stakeholder theory: Reviewing a theory that moves us. Journal of Management, 34(6): 1152-89.

http://dx.doi.org/10.1177/0149206308324322

Leavitt, T. 1958. The dangers of social responsibility. Harvard Business Review, 36: $41-50$.

Lee, I. B. 2005. Is there a cure for corporate "psychopathy"? American Business Law Journal, 42(1-6): 65-90.

Lindblom, C. E. 2002. The market system: What it is, how it works, and what to make of it. New Haven, Conn.: Yale University Press.

Lipsey, R. G., \& Lancaster, K. 1956. The general theory of second best. Review of Economic Studies, 24(1): 11-32. http://dx.doi.org/10.2307/2296233

Machold, S., Ahmed, P. K., \& Farquhar, S. S. 2008. Corporate governance and ethics: A feminist perspective. Journal of Business Ethics, 81(3): 665-78. http://dx.doi.org/10.1007/s10551-007-9539-5

MacKenzie, D. A. 2006. An engine, not a camera: How financial models shape markets. Cambridge, Mass.: MIT Press.

Maitland, I. 1994. The morality of the corporation: An empirical or normative disagreement? Business Ethics Quarterly, 4: 445-58. http://dx.doi.org/10.2307/3857343

Marcoux, A. M. 2000. Balancing act. In J. R. DesJardins \& J. J. McCall (Eds.), Contemporary issues in business ethics: 92-98. Stamford, Conn.: Wadsworth/Thomson Learning.

Margolis, J. D., \& Walsh, J. P. 2003. Misery loves companies: Rethinking social initiatives by business. Administrative Science Quarterly, 48(2): 268-305. http://dx.doi.org/10.2307/3556659

Marks, N., Abdallah, S., Simms, A., \& Thompson, S. 2006. The happy planet index. London: New Economics Foundation.

Marx, K. 1867. Das Capital. Hamburg: Verlag von Otto Meissner.

Matheson, J. H., \& Olson, B. A. 1991. Corporate law and the longterm shareholder model of corporate governance. Minnesota Law Review, 76: 1313-92.

McNulty, P. 1968. Economic theory and the meaning of competition. Quarterly Journal of Economics, 637-56. 
Meyer, R. E., \& Höllerer, M. A. 2010. Meaning structures in a contested issue field: A topographic map of shareholder value in Austria. Academy of Management Journal, 53(6): 1241-62. http://dx.doi.org/10.5465/AMJ.2010.57317829

Mill, J. S. 1863. Utilitarianism. London: Parker, Son, and Bourn.

Mohr, L. A., Webb, D. J., \& Harris, K. E. 2001. Do consumers expect companies to be socially responsible? The impact of corporate social responsibility on buying behavior. Journal of Consumer Affairs, 35(1): 45-72.

http://dx.doi.org/10.1111/j.1745-6606.2001.tb00102.x

Moore, G. 2012. The virtue of governance, the governance of virtue. Business Ethics Quarterly, 22(2): 293-318. http://dx.doi.org/10.5840/beq201222221

Nickerson, C., Schwarz, N., Diener, E., \& Kahneman, D. 2003. Zeroing in on the dark side of the American dream: A closer look at the negative consequences of the goal for financial success. Psychological Science, 14(6): 531-36. http://dx.doi.org/10.1046/j.0956-7976.2003.psci_1461.x

Offer, A. 2006. The challenge of affluence: Self-control and well-being in the United States and Britian since 1950. Oxford: Oxford University Press.

Orlitzky, M. 2011. Institutional logics in the study of organizations: The social construction of the relationship between corporate social and financial performance. Business Ethics Quarterly, 21(3): 409. http://dx.doi.org/10.5840/beq201121325

Orlitzky, M., Schmidt, F. L., \& Rynes, S. L. 2003. Corporate social and financial performance: A meta-analysis. Organization Studies, 24(3): 403-41. http://dx.doi.org/10.1177/0170840603024003910

Orr, D. V. 1998. Strategic bankruptcy and private pension default. Journal of Economic Issues, 669-87.

Oswald, A. J. 1997. Happiness and economic performance. Economic Journal, 107: 1815-31. http://dx.doi.org/10.1111/j.1468-0297.1997.tb00085.x

Pareto, V. 1971. Manual of political economy. New York: Augustus Kelley.

Payne, G. T., Brigham, K. H., Broberg, J. C., Moss, T. W., \& Short, J. C. 2011. Organizational virtue orientation and family firms. Business Ethics Quarterly, 21(2): 257-85.

Phillips, R. A. 1997. Stakeholder theory and a principle of fairness. Business Ethics Quarterly, 7: 51-66. http://dx.doi.org/10.2307/3857232

2003. Stakeholder theory and organizational ethics. San Francisco: Berrett-Koehler.

Posner, R. A. 1979. Utilitarianism, economics, and legal theory. Journal of Legal Studies, 8(1): 103-40. http://dx.doi.org/10.1086/467603

Post, J. E., Preston, L. E., \& Sachs, S. 2002. Redefining the corporation: Stakeholder management and organizational wealth. Stanford, Calif.: Stanford University Press.

Pye, A. 2002. The changing power of "explanations": Directors, academics and their sensemaking from 1989 to 2000. Journal of Management Studies, 39(7): 907-25. http://dx.doi.org/10.1111/1467-6486.00317 
Quinn, D., \& Jones, T. M. 1995. An agent morality view of business policy. Academy of Management Review, 20: 22-42.

Rappaport, A. 1986. Creating shareholder value: A guide for managers and investors. New York: The Free Press.

Ratner, R. K., \& Miller, D. T. 2001. The norm of self-interest and its effects on social action. Journal of Personality and Social Psychology, 81(1): 5-16. http://dx.doi.org/10.1037/0022-3514.81.1.5

Rebérioux, A. 2002. European style of corporate governance at the crossroads. JCMS: Journal of Common Market Studies, 40(1): 111-34. http://dx.doi.org/10.1111/1468-5965.00346

2007. Does shareholder primacy lead to a decline in managerial accountability? Cambridge Journal of Economics, 31(4): 507-24. http://dx.doi.org/10.1093/cje/bem009

Schwartz, M. S. 2006. God as a managerial stakeholder? Journal of Business Ethics, 66(2-3): 291-306. http://dx.doi.org/10.1007/s10551-005-5599-6

Schyns, P. 2003. Income and life satisfaction: A cross-national and longitudinal study. Delft, Netherlands: Eburon.

Scott, W. R. 1995. Institutions and organizations. Thousand Oaks, Calif.: Sage.

Sheehy, B. 2005. Scrooge-The reluctant stakeholder: Theoretical problems in the shareholder-stakeholder debate. University of Miami Business Law Review, 14: 193-240.

Shiller, R. 2000. Irrational exuberance. Princeton, N.J.: Princeton University Press.

Sidgwick, H. 1879. The establishment of ethical first principles. Mind, 4(13): 106-11. http://dx.doi.org/10.1093/mind/os-4.13.106

Singer, P. A. D. 2011. Practical ethics (3rd ed.). Cambridge: Cambridge University Press. http://dx.doi.org/10.1017/CBO9780511975950

Smith, A. 1776. An inquiry into the nature and causes of the wealth of nations. Chicago: University of Chicago Press.

Smith, D. G. 1998. The shareholder primacy norm. Journal of Corporate Law, 23: 277-310.

Solomon, R. C. 1992. Ethics and excellence: Cooperation and integrity in business. Oxford: Oxford University Press.

Soule, E., Hedahl, M., \& Dienhart, J. 2009. Principles of managerial moral responsibility. Business Ethics Quarterly, 19(4): 529-52.

Stern, N. 2007. The economics of climate change: The Stern review. Cambridge: Cambridge University Press.

Stigler, G. J. 1957. Perfect competition, historically contemplated. Journal of Political Economy, 65: 1-16. http://dx.doi.org/10.1086/257878

Stout, L. A. 2002. Bad and not-so-bad arguments for shareholder primacy. Southern California Law Review, 75: 1189-1210.

. 2012. The shareholder value myth: How putting shareholders first harms investors, corporations, and the public. San Francisco: Berrett-Koehler Publishers. 
Sundaram, A. K., \& Inkpen, A. C. 2004. The corporate objective revisited. Organization Science, 15: 350-63. http://dx.doi.org/10.1287/orsc.1040.0068

Tinsley, C. H., O'Connor, K. M., \& Sullivan, B. A. 2002. Tough guys finish last: The perils of a distributive reputation. Organizational Behavior and Human Decision Processes, 88(2): 621-42. http://dx.doi.org/10.1016/S0749-5978(02)00005-5

Turban, D. B., \& Greening, D. W. 1997. Corporate social performance and organizational attractiveness to prospective employees. Academy of Management Journal, 40(3): 658-72. http://dx.doi.org/10.2307/257057

Uzzi, B. 1996. The sources and consequences of embeddedness for the economic performance of organizations: The network effect. American Sociological Review, 61: 674-98. http://dx.doi.org/10.2307/2096399

1997. Social structure and competition in interfirm networks: The paradox of embeddedness. Administrative Science Quarterly, 42(1): 35-67. http://dx.doi.org/10.2307/2393808

van Oosterhout, H. J., Heugens, P. M. A. R., \& Kaptein, M. 2006. The internal morality of contracting: Advancing the contractualist endeavor in business ethics. Academy of Management Review, 31(3): 521-39. http://dx.doi.org/10.5465/AMR.2006.21318915

Velamuri, S. R., \& Venkataraman, S. 2005. Why stakeholder and stockholder theories are not necessarily contradictory: A Knightian insight. Journal of Business Ethics, 61: 249-62. http://dx.doi.org/10.1007/s10551-005-4733-9

Wallman, S. M. H. 1998. Understanding the purpose of a corporation: An introduction. Journal of Corporation Law, 24: 807-18.

Walsh, J. P., Weber, K., \& Margolis, J. D. 2003. Social issues and management: Our lost cause found. Journal of Management, 29(6): 859-81.

White, R. E. 1986. Generic business strategies, organizational context and performance: An empirical investigation. Strategic Management Journal, 7(3): 217-31. http://dx.doi.org/10.1002/smj.4250070304

Wicks, A. C., Gilbert, D. R., \& Freeman, R. E. 1994. A feminist reinterpretation of the stakeholder concept. Business Ethics Quarterly, 4: 475-98. http://dx.doi.org/10.2307/3857345

Zaheer, A., McEvily, B. B., \& Perrone, V. 1998. Does trust matter? Exploring the effects of interorganizational and interpersonal trust on performance. Organization Science, 9: $141-59$. 